\title{
Vitamin D: Which Way are we Headed?
}

\author{
Sadat-Ali $\mathbf{M}^{*}$ \\ Department of Orthopaedic Surgery, Saudi Arabia \\ *Corresponding author: Sadat-Ali M, Department of Orthopaedic Surgery, AlKhobar, Saudi Arabia \\ Submission: 㭰 October 21, 2017: Published: 眥 November 13, 2017
}

\section{Opinion}

The first scientific description of vitamin D-deficiency, namely rickets, was provided in the 17 th century by both Dr. Daniel Whistler (1645) and Professor Francis Glisson (1650). In 1919 Mellan by proposed that rickets is due to the absence of a fat-soluble dietary factor and in 1925 McCollum and co-workers named theantirachitic factor Vitamin D [1]. For decades vitamin D remained under the domain of pediatricians and orthopaedic surgeons for the treatment of rickets and osteomalacia. In later part of the last century, the management of osteoporosis brought vitamin D in the forefront and since then has occupied the minds of the health care givers, patients and the general population at large. In the last 30 years more 53000 papers world over and 214 from Saudi Arabia are cited in www.pubmed.gov [2] related to Vitamin D and search in Google on "Vitamin D" gave 62,400,000 active sites [3].

Reports in the literature suggest that in the world today one billion people from all ethnic and age groups lack adequate levels of Vitamin D. Extensive study from all regions of Saudi Arabia put the deficiency in 1983 between 0 and 30 percent [4], while in 2008 and 2009 [5,6] the figures in eastern province reached about 50\%, but recent figures reports of vitamin D deficiency up to $99.03 \%$ [7]. Recently reported figures of deficiency are $62.65 \%$ of female Saudis and $40.6 \%$ of male Saudis aged 15 years and above are deficient in vitamin D [8].

Vitamin D (25-hydroxy vitamin D-25 OHD) levels have been classified as normal ( $\geq 30 \mathrm{ng} / \mathrm{ml})$, insufficiency between (21 and $29 \mathrm{ng} / \mathrm{ml}$ ) and deficiency $\leq 20 \mathrm{ng} / \mathrm{ml}$. On these levels it was reported the world over the deficiency and insufficiency is quite high among various ethnic populations, even though people are not showing signs and symptoms related to very low levels of 25 OHD. Keeping in mind recently Janz \& Pearson [9] in Canada conducted a survey and on 25 OHD levels and a level of $(12 \mathrm{ng} / \mathrm{ml})<30 \mathrm{nmol} / \mathrm{L}$ to represent the deficiency level was recommended and at this level only $32 \%$ of the population lies in the vitamin D deficiency status. Similarly in United Kingdom in agreement with the Institute of Medicine (IOM), it was adopted that in respect to bone health of Serum 25 OHD $(12 \mathrm{ng} / \mathrm{ml})<30 \mathrm{nmol} / \mathrm{L}$ is to be regarded as deficient [10] This was recommended by more than 12 reputed associations in United Kingdom.
Second issue which need to be addressed is the assays used in testing the levels of 25 OHD. Different labs have different assays which give different results and this confuses the treating physician and the patients alike. There is lack of result comparability between different assays and often even between the same assays performed in different laboratories [11]. Snellman et al. [12] showed that level of $250 \mathrm{HD}$ by HPLC was $85 \mathrm{nmol} / \mathrm{l}$ and by CLIA it was $55 \mathrm{nmol} / \mathrm{l}$. Recently Sadat et al. [13] showed very similar results among Saudi Population of $22 \mathrm{ng} / \mathrm{ml}$ to $9 \mathrm{ng} / \mathrm{ml}$ when LCMS/MS was compared with CLIA. This indicated that when assays other than HPLC/ LCMS are used there is a false positive of insufficiency and deficiency.

Lastly, a onetime and single test of 250HD level cannot be taken as confirmative of deficiency or insufficiency. High levels of Parathyroid hormone (PTH) are definitely associated with low levels of 25 OHD. Hence without corroboration between 25 OHD levels and PTH levels may not be correct. In a recent study among Saudi population it was found that in all patients with vitamin D deficiency assessed by LCMS/MS, PTH level has high [14]. Thus is cases a normal PTH level will indicate a normal Vitamin D level even though CLIA may indicate deficiency or insufficiency of vitamin D.

We believe that time has come where researchers in the field should come to a consensus to bring the level of $250 \mathrm{HD}$ to $12 \mathrm{ng} / \mathrm{ml}$ or any reasonable level based on the requirement of our population for disease prevention. A standard approach will help in calming down the apprehensions and worries of patients at large, who believe that they have vitamin D deficiency even though they may not. Lastly a concerted effort with formulating and implementing guidelines will help the health care providers in taking appropriate decisions in the good clinical practice and ultimately better health care of the population.

\section{References}

1. Norman AW (1979) Vitamin D. The calcium homeostatic steroid hormone. Academic Press, San Francisco, UK.

2. WWW.pubmed.gov Accessed February 2016

3. WWW.Google.comAccessed February 2016.

4. Sedrani SH, Elidrissy AW, El Arabi KM (1983) Sunlight and vitamin D status in normal Saudi subjects. Am J Clin Nutr 38(1): 129-132. 
5. Al-Turki HA, Sadat-Ali M, Al-Elq AH, Al-Mulhim FA, Al-Ali AK (2008) 5-Hydoxyvitamin D levels among healthy Saudi Arabian women. Saudi Med J 29(12):1765-1768.

6. Sadat-Ali M, Al-Elq A, Al-Turki H, Al-Mulhim F, Al-Ali A (2009) Vitamin D levels in healthy men in eastern Saudi Arabia. Ann Saudi Med 29(5): 378-382.

7. Al-Elq AH (2012) status of Vitamin D in medical students in the preclerkship years of a Saudi medical school. J Family Community Med 19(2): 100-104.

8. Tuffaha M, El Bcheraoui C, Daoud F, Al Hussaini HA, Alamri F, et al. (2015) Deficiencies Under Plenty of Sun: Vitamin D Status among Adults in the Kingdom of Saudi Arabia, 2013. N Am J Med Sci 7(10): 467-475.

9. Janz T, Pearson C (2013) Health at a glance: Vitamin D Blood levels of Canadians. Statistics Canada. Catalogue no 82-624.
10. Francis R, Aspray T, Fraser W, Gittoes N, Javaid K, et al. (2013) Vitamin D and Bone Health: A Practical Clinical Guideline for Patient Management. National Osteoporosis Society 1-27.

11. Singh R (2008) Are clinical laboratories prepared for accurate testing of 25-hydroxy vitamin D? Clin Chem 54(1): 222-223.

12. Snellman G, Melhus H, Gedeborg R, Byberg L, Berglund L, et al. (2010) Determining Vitamin D status: A comparison between commercially available assays. PLos One 5(7): e11555.

13. Sadat-Ali M, Al-Elq AH, Al-Shaikh IH, Al-Turki HA, Al-Ali AK, et al. (2014) Assessment of low vitamin D among Saudi Arabians Did we overshoot the runway? Saudi Med J 35(10): 1243-1249.

14. Sadat-Ali M, Al-Omran AS, Al-Turki HA (2015) Parathyroid Glands response to Low Vitamin D levels in Healthy Adults: A Cross-Sectional Study. Ulster Med J 84(1): 26-29. 